\title{
Tumor Necrosis Factor Receptor 1 Is a Negative Regulator of Progenitor Proliferation in Adult Hippocampal Neurogenesis
}

\author{
Robert E. Iosif, ${ }^{1,4}$ Christine T. Ekdahl, ${ }^{1,4}$ Henrik Ahlenius, ${ }^{3,4}$ Cornelis J. H. Pronk, ${ }^{2,4}$ Sara Bonde, ${ }^{1,4}$ Zaal Kokaia, ${ }^{3,4}$ \\ Sten-Eirik W. Jacobsen, ${ }^{2,4}$ and Olle Lindvall ${ }^{1,4}$ \\ ${ }^{1}$ Laboratory of Neurogenesis and Cell Therapy, Section of Restorative Neurology, Wallenberg Neuroscience Center, ${ }^{2}$ Hematopoietic Stem Cell Laboratory, \\ and ${ }^{3}$ Laboratory of Neural Stem Cell Biology, Section of Restorative Neurology, Stem Cell Institute, University Hospital, SE 22184 Lund, Sweden, and ${ }^{4}$ Lund \\ Strategic Research Center for Stem Cell Biology and Cell Therapy, SE 22184 Lund, Sweden
}

Tumor necrosis factor- $\alpha$ (TNF- $\alpha$ ) is a proinflammatory cytokine, acting through the TNF-R1 and TNF-R2 receptors. The two receptors have been proposed to mediate distinct TNF- $\alpha$ effects in the CNS, TNF-R1 contributing to neuronal damage and TNF-R2 being neuroprotective. Whether TNF- $\alpha$ and its receptors play any role for neurogenesis in the adult brain is unclear. Here we used mouse models with loss of TNF-R1 and TNF-R2 function to establish whether signaling through these receptors could influence hippocampal neurogenesis in vivo under basal conditions, as well as after status epilepticus (SE), which is associated with inflammation and elevated TNF- $\alpha$ levels. Notably, in the intact brain, the number of new, mature hippocampal neurons was elevated in $T N F-R 1^{-/-}$and TNF-R1/R2 $2^{-/-}$mice, whereas no significant changes were detected in TNF- $R 2^{-/-}$mice. Also after SE, the TNF- $R 1^{-/-}$and TNF-R1/R2 ${ }^{-/-}$mice produced more new neurons. In contrast, the TNF- $R 2^{-/-}$mice showed reduced SE-induced neurogenesis. Cell proliferation in the dentate subgranular zone was elevated in TNF-R $1^{-/-}$and TNF-R1/R2 $2^{-/-}$mice both under basal conditions and after SE. The TNF-R2 $2^{-/-}$mice either showed no change or minor decrease of cell proliferation. TNF-R1 and TNF-R2 receptors were expressed by hippocampal progenitors, as assessed with reverse transcription-PCR on sorted or cultured cells and immunocytochemistry on cultures. Our data reveal differential actions of TNF-R1 and TNF-R2 signaling in adult hippocampal neurogenesis and identify for the first time TNF-R1 as a negative regulator of neural progenitor proliferation in both the intact and pathological brain.

Key words: TNF receptors; stem cells; neurogenesis; status epilepticus; hippocampus; inflammation

\section{Introduction}

Tumor necrosis factor- $\alpha$ (TNF- $\alpha$ ) is a proinflammatory cytokine believed to be involved in the pathogenesis of several acute and chronic neurodegenerative disorders, such as Parkinson's disease, multiple sclerosis, and stroke (Navikas and Link, 1996; Hallenbeck, 2002; Hirsch et al., 2003). TNF- $\alpha$ probably also has a role in normal brain function, e.g., the regulation of synaptic plasticity (Pickering et al., 2005). A variety of cell types can produce TNF- $\alpha$, but the major source of TNF- $\alpha$ in the CNS is activated microglia (Gebicke-Haerter, 2001). The action of TNF- $\alpha$ is complex and associated with both cell death and cell survival, depending on, for example, type of target cells and receptors (Hallenbeck, 2002; Wajant et al., 2003). TNF- $\alpha$ exerts its biological effects through activation of two distinct receptor subtypes,

Received March 2, 2006; revised Aug. 14, 2006; accepted Aug. 15, 2006.

This work was supported by the Swedish Research Council, European Union Project LSHBCT-2003-503005 (European Consortium for Stem (ell Research), and the Söderberg, (rafoord, and Kock Foundations. We thank M. Lundahl, U. Sparrhult-Björk, and B. Mattsson for technical help and Z. Ma for assistance with cell sorting.

Correspondence should be addressed to Olle Lindvall, Laboratory of Neurogenesis and Cell Therapy, Section of Restorative Neurology, Wallenberg Neuroscience Center, Lund University Hospital, 22184 Lund, Sweden. E-mail: olle.lindvall@med.lu.se.

DOI:10.1523/JNEUROSCI.2723-06.2006

Copyright $\odot 2006$ Society for Neuroscience $\quad$ 0270-6474/06/269703-10\$15.00/0
TNF-R1 and TNF-R2 (Wajant et al., 2003). TNF-R1 contains an intracellular "death domain" and contributes to neuronal death, whereas TNF-R2 can be neuroprotective (Fontaine et al., 2002; Yang et al., 2002; Marchetti et al., 2004) or induce apoptosis (Depuydt et al., 2005).

Recent experimental evidence suggests that TNF- $\alpha$ may influence the survival of new neurons generated from the neural stem cells of the adult brain in the dentate gyrus subgranular zone (SGZ) and the subventricular zone, lining the lateral ventricles. First, inflammation was found to be detrimental for the survival of the new hippocampal neurons formed in the early phase after status epilepticus (SE) as well as after lipopolysaccharide administration (Ekdahl et al., 2003; Monje et al., 2003). TNF- $\alpha$ is released from microglia during inflammation and, in accordance with a neurotoxic role, microglia-derived TNF- $\alpha$ compromised the survival of a hippocampal progenitor cell line in vitro (Cacci et al., 2005). Second, infusion of an antibody to TNF- $\alpha$ reduced the number of striatal and hippocampal neuroblasts generated after stroke, possibly by inhibiting a neuroprotective action of TNF- $\alpha$ mediated via TNF-R2 (Heldmann et al., 2005).

Progenitor cells isolated from rat hippocampus express TNF- $\alpha$ (Klassen et al., 2003) and from neonatal rat striatum express TNF-R1 (Ben-Hur et al., 2003), whereas both TNF-R1 and 
TNF-R2 were detected on cultured neural progenitors from human fetal brain (Sheng et al., 2005). These findings suggest that TNF- $\alpha$ may act directly on the multipotent neural progenitor cells, via either autocrine mechanisms or release from neighboring microglia cells. Moreover, the expression of both receptor subtypes on the progenitors themselves raises the possibility that TNF-R1 and TNF-R2 signaling not only regulates neuronal survival but also has other actions in neurogenesis. Interestingly, TNF- $\alpha$ has been shown to affect proliferation of hematopoietic stem/progenitor cells (Bryder et al., 2001; Dybedal et al., 2001; Chen et al., 2004), but none of these studies demonstrated a physiological role of TNF- $\alpha$ in the regulation of steady-state hematopoiesis. TNF- $\alpha$ was also found to suppress cell proliferation in neurospheres from neonatal rat striatum in vitro (Ben-Hur et al., 2003) and to promote proliferation of oligodendrocyte progenitors and remyelination in a mouse model of demyelination (Arnett et al., 2001). Whether signaling through TNF receptors controls neural progenitor proliferation and neurogenesis in the adult brain in vivo under basal conditions and after injury is unknown.

Here we demonstrate for the first time that signaling through TNF receptors regulates proliferation of neural progenitor cells in both the intact and pathological adult brain. Using mice in which both receptor subtypes had been deleted, we provide evidence that TNF-R1 and TNF-R2 have differential actions in hippocampal neurogenesis. TNF-R1 acts as a suppressor of progenitor proliferation, whereas TNF-R2 can improve survival of the newly formed neurons.

\section{Materials and Methods}

Animals and surgery. All experimental procedures followed guidelines set by the Malmö-Lund Ethical Committee for the use and care of laboratory animals. TNF-R1/R2 $2^{-/-}$mice (Peschon et al., 1998), backcrossed for five generations into wild-type C57BL/6 mice, were purchased from The Jackson Laboratory (Bar Harbor, ME). We generated TNF-R1 $1^{-1-}$ and $T N F-R 2^{-/-}$mice by crossing TNF-R1/R2 $2^{-/-}$to wild-type C57BL/6 mice (B \& K Universal, Stockholm, Sweden) and interbreeding heterozygous offspring, followed by selection of appropriate genotypes as determined by PCR. Wild-type C57BL/6 mice, and in one experiment wild-type littermates generated from the sixth generation of heterozygous TNF-R1/ $R 2^{+/-}$breeders, were used as controls, giving similar results when basal neurogenesis was assessed (data not shown).

Adult male TNF-R1 $1^{-1-}(n=29), T N F-R 2^{-/-}(n=43)$, TNF-R1/ $R 2^{-/-}(n=35), T N F-R 1 / R 2^{+/+}(n=7)$, and wild-type C57BL/6 mice ( $n=32$ ), weighing $22-24 \mathrm{~g}$, were used for the in vivo studies. Nestingreen fluorescent protein (GFP) mice for sorting of hippocampal progenitors were a gift from Dr. G. Enikolopov (Cold Spring Harbor Laboratory, Cold Spring Harbor, NY). Sprague Dawley rats $(n=6 ; 220-250$ g) used for hippocampal progenitor cultures were from B \& K Universal. Animals were housed separately under $12 \mathrm{~h}$ light/dark conditions with ad libitum access to water and food.

Eighty-five mice were anesthetized with halothane and implanted with a twisted insulated stainless-steel stimulating and recording electrode (Plastics One, Roanoke, VA) unilaterally into the ventral hippocampal CA1-CA3 region (coordinates: $2.9 \mathrm{~mm}$ caudal and $3.0 \mathrm{~mm}$ lateral to bregma, $3.0 \mathrm{~mm}$ ventral from dura, and tooth bar at $-3.3 \mathrm{~mm}$ ).

Induction of status epilepticus. Ten days after electrode implantation, 59 mice were subjected to electrically induced SE, as originally described by Lothman et al. (1989). Mice received $1 \mathrm{~h}$ of suprathreshold stimulation consisting of $10 \mathrm{~s}$ trains of $1 \mathrm{~ms}$ biphasic square wave pulses at a frequency of $50 \mathrm{~Hz}$. The stimulation was interrupted every $10 \mathrm{~min}$ for 1 min to allow for electroencephalogram (EEG) recording and measurement of afterdischarges (MacLab; AD Systems, Hastings, UK). After ending the stimulation, all mice exhibited self-sustained, continuous ictal hippocampal EEG activity, which was associated with varying severity of motor behavioral convulsions, categorized into partial and generalized seizures. The partial seizures comprised hyperactive motor behavior and were scored as grade $0-2$ in the classic kindling motor behavior scale. The generalized seizures corresponded to clonic seizures rated as grade 3-5 (Racine, 1972). Both behavioral convulsions and ictal EEG activity were arrested in all mice with pentobarbital ( $40 \mathrm{mg} / \mathrm{kg}$, i.p.) at $2 \mathrm{~h}$ after stimulation offset.

Bromodeoxyuridine administration and group assignment. Mice were divided into four treatment groups and given bromodeoxyuridine (BrdU) injections [50 mg/kg, i.p., dissolved in potassium PBS (KPBS)]. (1) Naive mice $(n=42)$ were injected with BrdU twice daily for 2 weeks to label a substantial number of new cells and were allowed to survive for 2 weeks thereafter. (2) Naive mice $(n=19)$ received BrdU injections every $2 \mathrm{~h}$ during a $6 \mathrm{~h}$ period and were perfused $2 \mathrm{~h}$ later. (3) Mice subjected to SE $(n=31)$ and nonstimulated, electrode-implanted controls $(n=14)$ were given BrdU injections twice daily during 1 week, starting $7 \mathrm{~d}$ after SE at the peak of the SE-induced proliferation (Parent et al., 1997) and were perfused 4 weeks after last injection. (4) Mice subjected to SE $(n=28)$ and nonstimulated, electrode-implanted controls $(n=12)$ received BrdU injections every $2 \mathrm{~h}$ during a $6 \mathrm{~h}$ period, starting $7 \mathrm{~d}$ after SE, and were perfused $2 \mathrm{~h}$ after the last BrdU injection.

Immunohistochemistry. Mice received an overdose of anesthesia (sodium pentobarbital; $200 \mathrm{mg} / \mathrm{kg}$, i.p.) and were transcardially perfused with $100 \mathrm{ml}$ of saline, followed by $100 \mathrm{ml}$ of ice-cold formaldehyde solution [ $4 \%$ paraformaldehyde (PFA) in $0.1 \mathrm{M} \mathrm{PBS,} \mathrm{pH} \mathrm{7.4].} \mathrm{Brains} \mathrm{were}$ removed, postfixed overnight in the same medium, and placed in $20 \%$ sucrose in $0.1 \mathrm{~m}$ phosphate buffer for $24 \mathrm{~h}$. Coronal sections $(30 \mu \mathrm{m})$ were cut on a freezing microtome and stored in cryoprotective solution.

For BrdU and neuron-specific nuclear protein (NeuN) double-labeled immunofluorescence, free-floating sections were denatured in $1 \mathrm{M} \mathrm{HCl}$ for $30 \mathrm{~min}$ at $+65^{\circ} \mathrm{C}$, rinsed in KPBS (to neutralize $\mathrm{pH}$ ), preincubated with $2 \%$ goat and donkey serum in $0.25 \%$ Triton X-100 for $1 \mathrm{~h}$, and incubated overnight with rat anti-BrdU antibody (1:100; Sigma, Stockholm, Sweden) and mouse anti-NeuN antibody (1:100; Chemicon, Temecula, $\mathrm{CA}$ ) at $+4^{\circ} \mathrm{C}$. Sections were then rinsed and incubated in the dark for $2 \mathrm{~h}$ with cyanine 3-conjugated donkey anti-rat IgG antibody (1:400; Jackson ImmunoResearch, West Grove, PA) and biotinylated horse anti-mouse IgG antibody (1:200; Vector Laboratories, Järfälla, Sweden), incubated in streptavidin Alexa Fluor 488 (1:200; Invitrogen, Carlsbad, CA) in the dark for $2 \mathrm{~h}$, mounted on glass slides, and coverslipped with glycerol-based mounting medium (for fluorescence microscopy).

For staining of proliferating cell nuclear antigen (PCNA), phosphorylated histone $\mathrm{H} 3$ ( $\mathrm{p}-\mathrm{H} 3)$, ionized calcium-binding adapter molecule 1 macrophage/microglia-specific protein (Ibal), and $\mathrm{S} 100 \beta$ astrocytespecific marker $(\mathrm{S} 100 \beta)$, free-floating sections were quenched with $3 \%$ $\mathrm{H}_{2} \mathrm{O}_{2}$ and $10 \%$ methanol in KPBS for $30 \mathrm{~min}$ at room temperature, rinsed in KPBS (to neutralize $\mathrm{pH}$ ), preincubated for $1 \mathrm{~h}$ with $2 \%$ horse serum in $0.25 \%$ Triton X-100 for PCNA and $2 \%$ goat serum in $0.25 \%$ Triton X-100 for p-H3, Iba1, and S100 $\beta$. The sections were thereafter incubated overnight with mouse anti-PCNA antibody (1:1000; Santa Cruz Biotechnology, Santa Cruz, CA), rabbit anti-p-H3 antibody (1:400; Upstate, Charlottesville, VA), rabbit anti-Iba1 antibody (1:1000; Wako Chemicals, Neuss, Germany), or rabbit anti-S100 $\beta$ antibody (1:5000; Swant, Bellinzona, Switzerland) at $+4^{\circ} \mathrm{C}$, rinsed, and incubated with biotinylated horse anti-mouse IgG antibody (1:200; Vector Laboratories) for PCNA or biotinylated goat anti-rabbit IgG antibody (1:200; Vector Laboratories) for $\mathrm{p}-\mathrm{H} 3$, Iba1, and $\mathrm{S} 100 \beta$. The sections were then incubated with avidin-biotin-peroxidase complex (Elite ABC kit; Vector Laboratories) for $1.5 \mathrm{~h}$, treated with diaminobenzidine $(0.5 \mathrm{mg} / \mathrm{ml})$ and $3 \%$ hydrogen peroxide, and finally rinsed in KPBS, mounted on glass slides, and dehydrated in increasing concentrations of ethanol (70, 95, and $99 \%$ ), before being coverslipped with Pertex mounting medium for light microscopy.

For Fluoro-Jade staining, free-floating brains sections were mounted in KPBS and allowed to dry overnight. As described in detail previously (Schmued et al., 1997), sections were rehydrated, pretreated with $0.06 \%$ potassium permanganate for $15 \mathrm{~min}$, rinsed in distilled water, incubated in $0.01 \%$ Fluoro-Jade working solution (Histo-Chem, Jefferson, AR) for $30 \mathrm{~min}$, rinsed in distilled water, immersed in xylene, and coverslipped. 
Microscopic analysis. All assessments were performed by an observer blind to the treatment conditions. Immunostaining was examined with an Olympus Optical (Albertslund, Denmark) AX-70 light microscope. The number of immunoreactive cells was counted in the granule cell layer (GCL) and within two cell diameters below this region in the SGZ (referred to as SGZ/GCL). Stereological estimations of the total number of BrdU-positive $\left(\mathrm{BrdU}^{+}\right), \mathrm{Ibal}^{+}$, and $\mathrm{S} 100 \beta^{+}$cells in the SGZ/GCL of the dorsal hippocampal formation were performed using the optical fractionator method (Gundersen and Jensen, 1987; West et al., 1991). Three coronal sections, located $1.7-2.3 \mathrm{~mm}$ posterior to bregma, were analyzed using the Olympus Optical BH-2 microscope with a $100 \times$ oil objective, CCD-IRIS color video camera, and CAST-GRID software (Olympus Optical). For systematic sampling, the frame area was set to $1491.7 \mu \mathrm{m}^{2}$ with a counting interval of $40 \mu \mathrm{m}$ at the $x$ and $y$ level, and the optical dissector constituting a $5-\mu \mathrm{m}$-thick fraction of the total section thickness (measuring 7-9 $\mu \mathrm{m}$ ). Neither the area for counting nor the thickness of the analyzed sections (measured using the Heidenhain Microcator and CAST-GRID software) differed between groups, which allowed for comparisons of cell counts. The SGZ/GCL volume was measured using stereological equipment in the same sections. Because of their small numbers, counts of $\mathrm{p}-\mathrm{H} 3{ }^{+}$and $\mathrm{PCNA}^{+}$cells in the SGZ/GCL are given as cells per section.

Colocalization of BrdU-positive cells with $\mathrm{NeuN}$ was validated using a confocal scanning light microscope (MRC1024UV; Bio-Rad, Hemel Hempstead, UK) with krypton/argon 488 and 568 excitation filter. A double-stained cell was defined as having the strongest intensity of both stainings within the same or directly neighboring $1-\mu \mathrm{m}$-thick optical section through the cell in a consecutive $Z$-series of at least four sections, with an overlap of the stainings in at least three sections. In addition, a double-labeled cell showed no BrdU immunoreactivity outside the nucleus of the $\mathrm{NeuN}^{+}$cell body. Fifty BrdU-positive cells from each animal were analyzed for NeuN double labeling in the SGZ/GCL.

Cytokine measurement. Hippocampi from wild-type, TNF-R1 $1^{-/-}$, $T N F-R 2^{-/-}$, and TNF-R1/R2 $2^{-/-}$mice ( $n=7$ for all groups) were dissected and directly frozen on dry ice. Protein was extracted by homogenization in PBS with protease inhibitor cocktail (Sigma) on ice using a pellet pestle and motor (Sigma). The homogenate was cleared from cellular debris by centrifugation. Total protein was determined in the pellet using BCA protein assay (Pierce Endogen, Rockford, IL). The amount of interleukin- $1 \beta$ (IL-1 $\beta$ ), IL-6, and TNF- $\alpha$ in the homogenate was measured using ELISA (Pierce Endogen), and data are given as picograms per milligram of total hippocampal protein.

Cell culture. Neural progenitor cultures derived from adult rat hippocampus were initiated as described previously (Gage et al., 1995; Palmer et al., 1997). Briefly, rats were deeply anesthetized using halothane and decapitated, and brains were removed. Hippocampi were dissected, pooled, and dissociated in DMEM (Invitrogen, Stockholm, Sweden) containing $2.5 \mathrm{U} / \mathrm{ml}$ papain, $1 \mathrm{U} / \mathrm{ml}$ dispase II, and $250 \mathrm{U} / \mathrm{ml}$ DNase 1 (Worthington Biochemical, Stockholm, Sweden) for $45 \mathrm{~min}$ at $+37^{\circ} \mathrm{C}$. Dissociated cells were purified on two Percoll (Pharmacia, Uppsala, Sweden) gradients, 35 and $65 \%$. The resulting cells were cultured on poly-Lornithine (Invitrogen, Stockholm, Sweden) and laminin (Sigma) coated culture flasks or chamber slides in DMEM/F-12, supplemented with 15 mM HEPES, $2 \mathrm{~mm}$ L-glutamine, $100 \mathrm{U} / \mathrm{ml}$ penicillin, $100 \mathrm{mg} / \mathrm{ml}$ streptomycin, N2 supplement (Invitrogen, Stockholm, Sweden), and $20 \mathrm{ng} / \mathrm{ml}$ basic FGF (R \& D Systems, Abingdon, UK).

For immunocytochemistry, rat-derived progenitor cells were cultured on poly-L-ornithine/laminin-coated chamber slides, fixed with $4 \%$ PFA for $15 \mathrm{~min}$, and stained with mouse anti-TNF-R1 and goat anti-TNF-R2 antibodies (Santa Cruz Biotechnology) overnight at $+4^{\circ} \mathrm{C}$. Staining was visualized with horse anti-mouse and rabbit anti-goat biotinylated antibodies (Vector Laboratories) using TSA amplification kit (Becton Dickinson, Stockholm, Sweden) and streptavidin Alexa Fluor 488 (Invitrogen, Carlsbad, CA).

Cell sorting and reverse transcription-PCR. Hippocampi from nestinGFP mice were pooled and dissociated as above, and cells were purified on a $35 \%$ Percoll gradient. GFP-positive cells were sorted on a fluorescence-activated cell sorter [FACS DiVa (Becton Dickinson)] directly into cell lysis buffer. Total RNA from GFP-positive mouse cells and rat hippocampal progenitor cultures were isolated (RNAqueos for PCR; Ambion, Huntingdon, Cambridgeshire, UK) and reverse transcribed to cDNA using oligo-dT primers and Superscript II (Invitrogen, Stockholm, Sweden). PCR was performed with the following primers, annealing temperatures, and expected product size for mouse: glyceraldehyde3-phosphate dehydrogenase (GAPDH) sense, 5' TCACCATCTTCCAGGAGCGA 3' and antisense, 5'ACCAGGAAATGAGCTTGACA 3', $+56^{\circ} \mathrm{C}, 720 \mathrm{bp}$; TNF- $\alpha$ sense, $5^{\prime}$ ATGAGCACAGAAAGCATGATCCGCGAC $3^{\prime}$ and antisense, $5^{\prime}$ TCACAGAGCAATGACTCCAAAGTAGACCTG $3^{\prime},+62^{\circ} \mathrm{C}, 700$ bp; TNF-R1 sense, 5' CCGGGCCACCTGGTCCG $3^{\prime}$ and antisense, 5' CAAGTAGGTTCCTTTGTG $3^{\prime},+55^{\circ} \mathrm{C}$, $307 \mathrm{bp}$; and TNFR2 sense, 5' CTCGCGCTGGTCTTCGAACTG $3^{\prime}$ and antisense, 5' GGTATACATGCTTGCCTCACAGTC $3^{\prime}$, $+62^{\circ} \mathrm{C}, 234 \mathrm{bp}$ (Reddy et al., 2001). For rat, primers, annealing temperatures, and expected product sizes are as follows: GAPDH sense, $5^{\prime}$ TCCTGCACCACCAACTGCTTAGCC $3^{\prime}$ and antisense, $5^{\prime}$ TAGCCCAGGATGCCCTTTAGTGGG $3^{\prime},+60^{\circ} \mathrm{C}, 377 \mathrm{bp}$; TNF- $\alpha$ sense, $5^{\prime}$ TGGCCCAGACCCTCACACTC $3^{\prime}$ and antisense, $5^{\prime}$ CTCCTGGTATGAAATGGCAAATC $3^{\prime},+59^{\circ} \mathrm{C}, 281 \mathrm{bp}$; TNF-R1 sense, 5' GAACACCGTGTGTAACTGCC $3^{\prime}$ and antisense, 5' ATTCCTTCACCC TCCACCTC 3', $+59^{\circ} \mathrm{C}, 301 \mathrm{bp}$; and TNF-R2 sense, 5' GATGAGAAATCCCAGGATGCAGTAGG $3^{\prime}$ and antisense, $5^{\prime}$ TGCTACAGACGTTCACGATGCAGG $3^{\prime}+59^{\circ} \mathrm{C}, 264 \mathrm{bp}$ (Raina and Jeejeebhoy, 2004). The resulting products were visualized on ethidium bromide-containing $1.5 \%$ agarose gel and photographed in a UV transilluminator.

Statistical analysis. Comparisons were performed using one-way ANOVA, followed by post hoc Bonferroni-Dunn test. Data are presented as means \pm SEM, and differences are considered significant at $p<0.05$. Paired correlations were performed with $z$ test. All statistical analyses were conducted using StatView software, version 5.0.1 (Abacus Concepts, Berkeley, CA).

\section{Results}

\section{Deletion of TNF-R1 and TNF-R2 differentially affects} hippocampal neurogenesis

We first explored whether signaling through TNF-R1 and TNF-R2 could influence the formation of mature neurons in the dentate gyrus of the intact mouse brain. To label new cells, we used BrdU, a thymidine analog that is incorporated into DNA during cell division (Dolbeare, 1995). Adult TNF-R1 $1^{-/-}$and $T N F-R 2^{-/-}$mice were injected with BrdU twice daily during 2 weeks and perfused 2 weeks thereafter. The BrdU ${ }^{+}$cells were distributed mainly in the SGZ/GCL with no differences between animal groups. Deletion of the TNF-R1 gene caused a $25 \%$ increase in the number of $\mathrm{BrdU}^{+}$cells double labeled for the specific marker of mature neurons NeuN in the SGZ/GCL compared with wild-type animals (Fig. 1). No significant change in the number of $\mathrm{BrdU}^{+} / \mathrm{NeuN}^{+}$cells was observed in $T N F-R^{-/-}$ mice.

We then assessed whether absence of TNF-R1 and TNF-R2 influenced the formation of new mature hippocampal neurons also in the pathological mouse brain. Status epilepticus, which is defined as continuous seizures lasting for $30 \mathrm{~min}$ or more, gives rise to neuronal death, inflammation, and chronic seizures. This condition leads to elevated levels of TNF- $\alpha$ (De Simoni et al., 2000) and triggers increased cell proliferation and neurogenesis in the SGZ of both rats (Parent et al., 1997) and mice (Kralic et al., 2005). In rats, the seizure-generated mature neurons can survive for at least 6 months (Bonde et al., 2006). We induced SE by applying $1 \mathrm{~h}$ of electrical stimulation to the hippocampus (Lothman et al., 1989; Mohapel et al., 2004). During the subsequent $2 \mathrm{~h}$ of self-sustained SE, all groups of mice exhibited either partial (grade $0-2$ ) or generalized (grade 3-5) convulsive behavior (Fig. $2)$. The $T N F-R 1 / R 2^{-/-}$mice showed higher percentage of generalized convulsions compared with wild-type animals. No other behavioral differences were observed between the groups during 


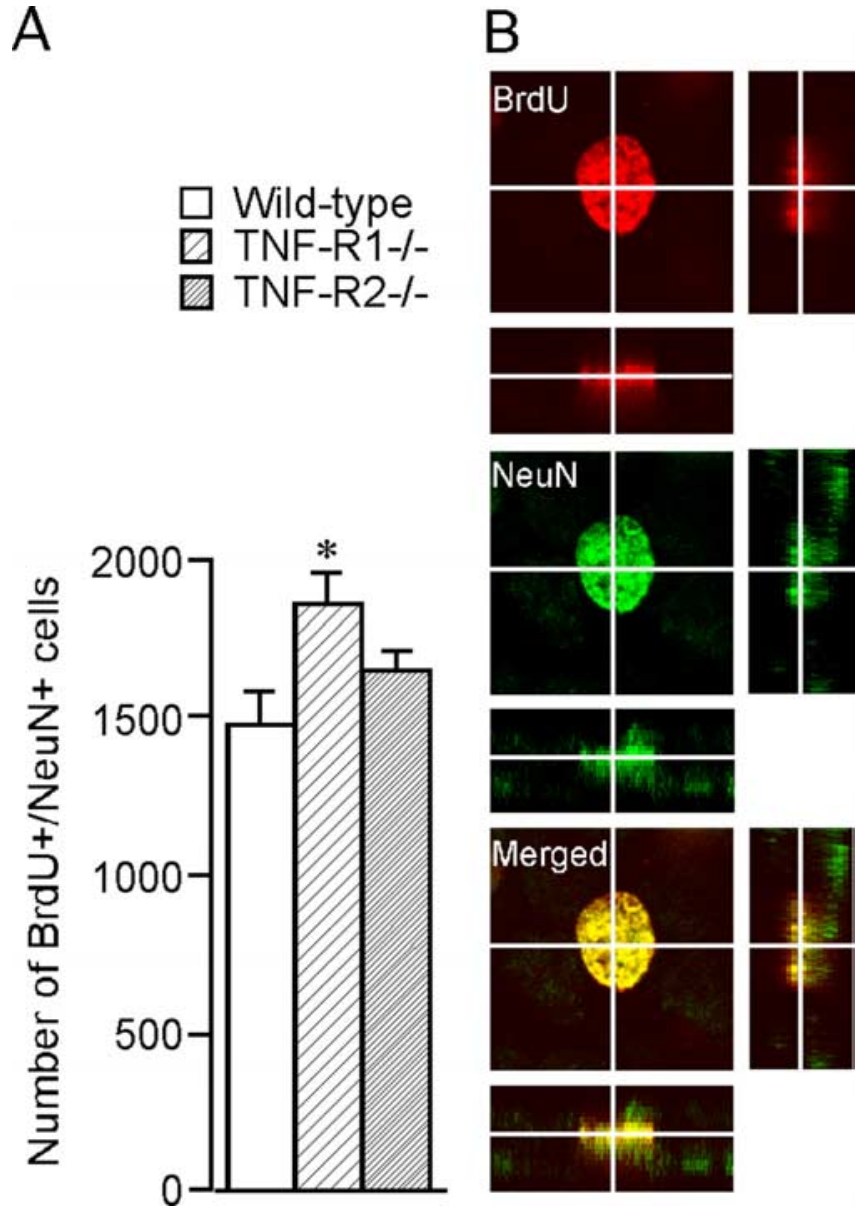

Figure 1. Deletion of TNF-R1 and TNF-R2 differentially affects basal hippocampal neurogenesis. $A$, Number of new mature neurons $\left(\mathrm{BrdU}^{+} / \mathrm{NeuN}^{+}\right)$in the dentate subgranular zone/ granule cell layer at 2 weeks after 2 weeks of daily BrdU injections. Means \pm SEM; $n=8,6$, and 15 for wild-type, $T N F-R 1^{-/-}$, and TNF-R2 ${ }^{-/-}$mice, respectively. ${ }^{*} p<0.05$ compared with wild-type, one-way ANOVA with Bonferroni-Dunn post hoc test. $\boldsymbol{B}$, Confocal images of a $\mathrm{BrdU}^{+} / \mathrm{NeuN}^{+}$cell showing BrdU and NeuN immunoreactivity separately or as merged image. Orthogonal reconstructions from confocal $Z$-series are presented as viewed in $x-z$ (bottom) and $y-z$ (right) planes.

SE. Moreover, the duration of electrical stimulation until the mice developed continuous ictal hippocampal EEG activity did not differ between wild-type $(36 \pm 1 \mathrm{~min})$ and $T N F-R 1^{-/-}(37 \pm$ $2 \mathrm{~min}), T N F-R 2^{-/-}(38 \pm 2 \mathrm{~min})$, and TNF-R1/R2 $2^{-/}(39 \pm 2$ min) mice.

Starting 1 week after SE, we injected BrdU for 1 week and perfused the animals 4 weeks later. The epileptic insult gave rise to a threefold increase of the number of $\mathrm{BrdU}^{+} / \mathrm{NeuN}^{+}$mature neurons in the SGZ/GCL of wild-type mice compared with their nonstimulated, electrode-implanted controls (data not shown). Interestingly, the deletion of TNF-R1 and TNF-R2 had opposing effects on the SE-induced neurogenesis (Fig. 3). Whereas the number of $\mathrm{BrdU}^{+} / \mathrm{NeuN}^{+}$cells in the SGZ/GCL was $19 \%$ higher in $T N F-R 1^{-/-}$compared with wild-type animals, the cell number in this area in TNF-R2 $2^{-/-}$mice was $31 \%$ lower than controls.

Because TNF-R2 has been proposed to interact with TNF-R1 (Wajant et al., 2003), we also studied mice lacking both receptors. Under steady-state conditions, the TNF-R1/R2 $2^{-/-}$mice showed $44 \%$ higher number of $\mathrm{BrdU}^{+} / \mathrm{NeuN}^{+}$cells than wild-type animals (Fig. 4). Similarly, at 6 weeks after SE, deletion of both receptors had given rise to $46 \%$ more $\mathrm{BrdU}^{+} / \mathrm{NeuN}^{+}$cells in the SGZ/GCL (Fig. 4). Although not directly comparable because the
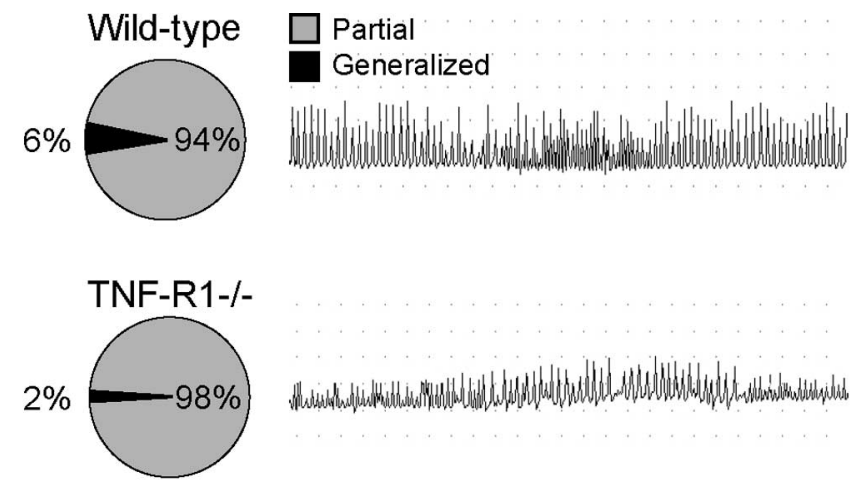

TNF-R2-/-

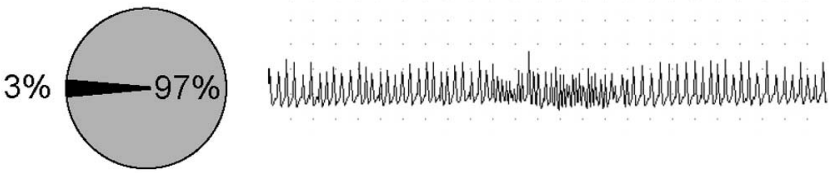

TNF-R1/R2-/-

$17 \%$
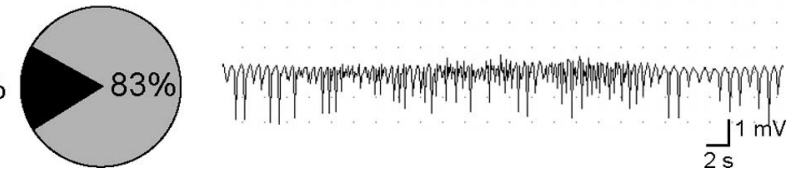

Figure 2. Relative distribution of different convulsive behaviors and EEG characteristics for

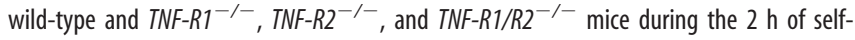
sustained status epilepticus. Ratings are based on Racine's (1972) scale. Grades $0-2$ and 3-5 represent partial and generalized convulsions, respectively. Each segment depicts the mean percentage of time spent exhibiting the behavior. Examples of typical hippocampal EEG recordings during SE are presented for each group.

data were generated from different experiments, it is worth noting that, both under basal conditions and after SE, the increase of new mature neurons in the absence of both receptors (Fig. 4) was almost doubled compared with after deletion of the TNF-R1 gene only (Figs. 1,3). This observation may suggest a possible cooperation between the two receptors also in hippocampal neurogenesis.

The volume of SGZ/GCL was not influenced by the deletion of the TNF- $\alpha$ receptors either in intact animals or after SE (TNF$R 1^{-/-}, 0.19$ and $0.18 \mathrm{~mm}^{3} ; T N F-R 2^{-/-}, 0.19$ and $0.18 \mathrm{~mm}^{3}$; TNF-R1/R2 $2^{-/-}, 0.18$ and $0.18 \mathrm{~mm}^{3}$; and wild-type, 0.18 and 0.18 $\mathrm{mm}^{3}$, respectively). We tested the hypothesis that the loss of TNF- $\alpha$ receptors had caused compensatory changes in the levels of other cytokines, which may have lead to the observed alterations of neurogenesis. Arguing against this possibility, no significant differences between TNF-R1 $1^{-1-}, T N F-R 2^{-1-}$, and TNF$R 1 / R 2^{-/-}$mice and wild-type animals were detected in hippocampal levels of TNF- $\alpha$, IL- $1 \beta$, or IL- 6 under basal conditions (supplemental Fig. 1, available at www.jneurosci.org as supplemental material). We found substantially higher (149\%) levels of TNF- $\alpha$ in the hippocampus of TNF-R1 $1^{-1-}$ compared with $T N F-R 1 / R 2^{-/-}$mice. It is highly unlikely, however, that this difference would have played any role for the observed changes in neurogenesis, which were very similar in the two strains.

\section{Deletion of TNF-R1 increases hippocampal progenitor proliferation}

We wanted to determine whether the alterations of basal and insult-induced neurogenesis caused by the absence of TNF-R1 and TNF-R2 could be attributable to changes in hippocampal 
A

Wild-type

TNF-R1-/TNF-R2-I-
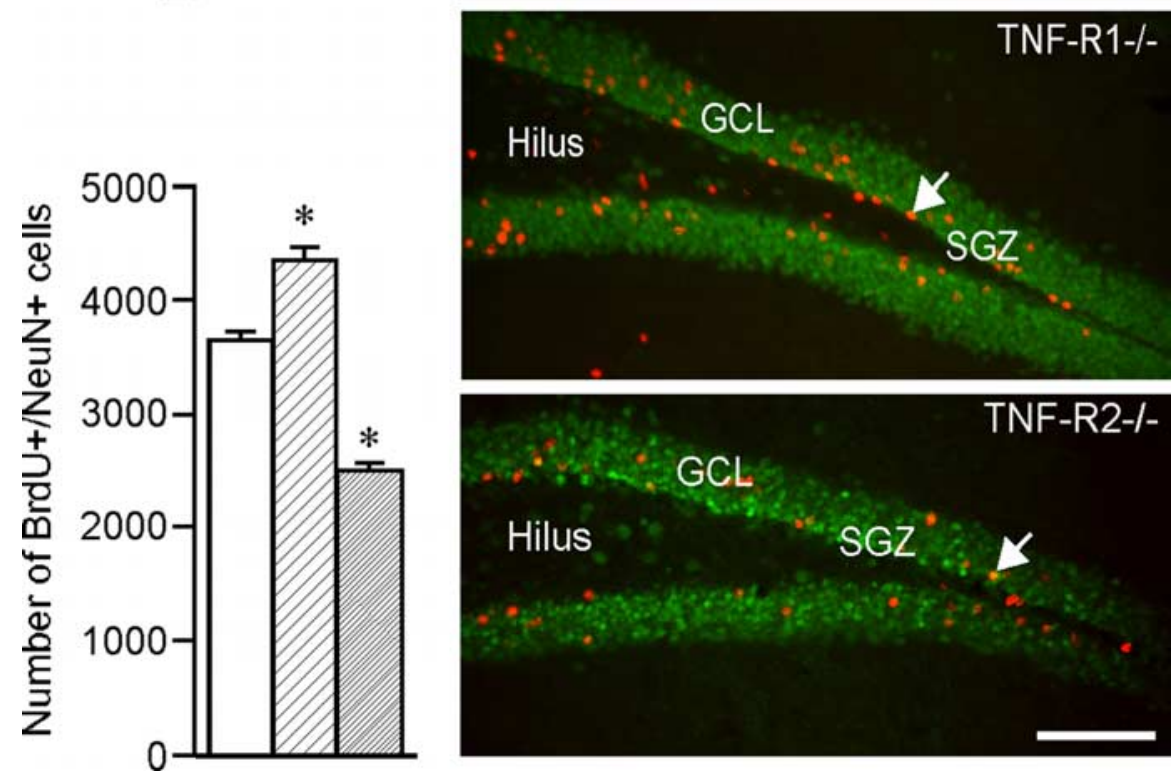

Figure 3. Deletion of TNF-R1 and TNF-R2 differentially affects hippocampal neurogenesis after status epilepticus. $\boldsymbol{A}$, Number of new mature neurons $\left(\mathrm{BrdU}^{+} / \mathrm{NeuN}^{+}\right)$in the dentate $\mathrm{SGZ} / \mathrm{GCL}$ at 4 weeks after 1 week of daily BrdU injections, which started 1 week after $2 \mathrm{~h}$ of electrically induced status epilepticus. Means $\pm \mathrm{SEM} ; n=6,6$, and 9 for wild-type, TNF-R1 ${ }^{-1-}$, and $T N F-R 2^{-1-}$ mice, respectively. ${ }^{*} p<0.05$ compared with wild-type, one-way ANOVA with Bonferroni-Dunn post hoc test. $\boldsymbol{B}$, Photomicrographs showing distribution of BrdU ${ }^{+}$(red) and NeuN ${ }^{+}$(green) cells in dentate gyrus. Some BrdU ${ }^{+} / \mathrm{NeuN}^{+}$cells (yellow) are depicted by arrows. Scale bar, $70 \mu \mathrm{m}$.
A

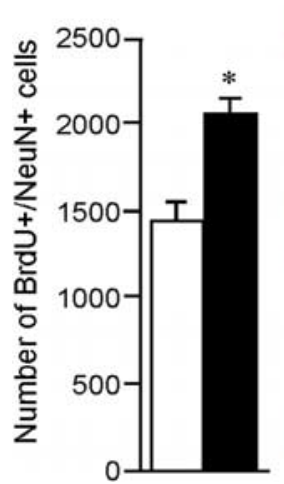

B

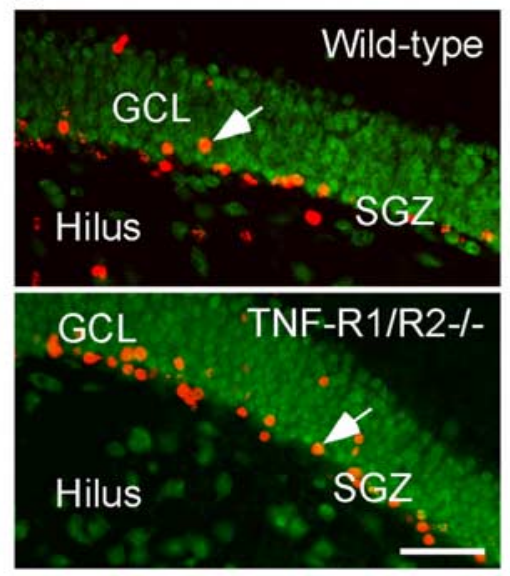

C

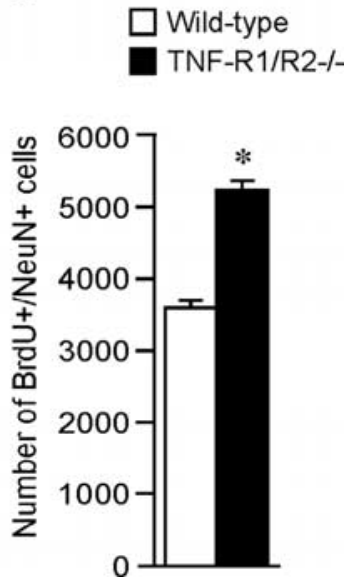

Figure 4. Deletion of both TNF-R1 and TNF-R2 increases hippocampal neurogenesis during basal conditions and after status epilepticus. A, C, Number of new mature neurons (BrdU $\left.{ }^{+} / \mathrm{NeuN}^{+}\right)$in the dentate SGZ/GCL of TNF-R1/R2 ${ }^{-/-}$mice at 2 weeks after 2 weeks of daily BrdU injections $(\boldsymbol{A})$ and at 4 weeks after 1 week of daily BrdU injections, which started 1 week after $2 \mathrm{~h}$ of electrically induced status epilepticus (C). Means \pm SEM; $n=5$ and 6 , and 6 and 10 for wild-type and TNF-R1/R2 $2^{-1}$ mice, respectively. ${ }^{*} p<0.05$ compared with wild-type, one-way ANOVA with Bonferroni-Dunn post hoc test. $B$, Photomicrographs showing distribution of $\mathrm{BrdU}^{+}$(red) and $\mathrm{NeuN}^{+}$(green) cells in dentate gyrus. Some BrdU ${ }^{+} / \mathrm{NeuN}^{+}$cells (yellow) are depicted by arrows. Scale bar, $70 \mu \mathrm{m}$. progenitor proliferation. Three different markers of cell proliferation were analyzed in the SGZ using immunohistochemistry: (1) BrdU, which was injected four times with $2 \mathrm{~h}$ interval and the animals were perfused $2 \mathrm{~h}$ thereafter; (2) p-H3, which labels the mitotic fraction of actively cycling cells (Komitova et al., 2005); and (3) PCNA, a protein involved in the major DNA replication and repair machinery of the cell (Paunesku et al., 2001).

Under basal conditions (Fig. 5A-C), there was a significant increase in the number of both $\mathrm{BrdU}^{+}$and $\mathrm{p}-\mathrm{H} 3{ }^{+}$cells and a similar trend for $\mathrm{PCNA}^{+}$cells in the SGZ of TNF-R1 $1^{-1-}$ mice. In contrast, the TNF-R2 $2^{-1-}$ mice showed no change in $\mathrm{BrdU}^{+}$and $\mathrm{p}-\mathrm{H}_{3}{ }^{+}$cells but a decrease in $\mathrm{PCNA}^{+}$cells. Compared with basal conditions (Fig. 5A-C), the epileptic insult gave rise to a several-fold increase of cell proliferation in the SGZ in all groups (Fig. 5DI). However, the changes in cell proliferation compared with wild-type animals differed between mice lacking TNF-R1 and TNF-R2. At 1 week after SE, all three markers were increased in TNF-R1 $1^{-/-}$ mice, whereas $\mathrm{BrdU}^{+}$cells were reduced and the number of $\mathrm{p}-\mathrm{H} 3^{+}$and $\mathrm{PCNA}^{+}$ cells remained unchanged in TNF- $R 2^{-1-}$ mice (Fig. $5 D, E$ ). In all animal groups, the majority of $\mathrm{BrdU}^{+}$cells formed clusters in the SGZ (Fig. 5G), as described previously in rats after SE (Parent et al., 1997; Mohapel et al., 2004). Both under basal conditions and after SE, we observed that, compared with wild-type animals, all three proliferation markers were increased to the same extent in the combined TNF-R1/ $R 2^{-1-}$ mice as in the TNF- $R 1^{-1-}$ mice (Fig. 5A-F). The differences in magnitude of changes between the BrdU, p-H3, and PCNA stainings were most likely dependent on the sensitivity of detection of the markers and the fact that they reveal different aspects of cell division.

Together, these findings provide strong evidence that TNF-R1 signaling acts to suppress hippocampal progenitor proliferation both under basal conditions in the intact brain and after injury. In contrast, TNF-R2 has at most a minor effect on cell proliferation in the SGZ.

Deletion of TNF-R1 and TNF-R2 affects microglia but not astrocytes or degenerating neurons in neurogenic area after status epilepticus

Microglia is a major source of TNF- $\alpha$, and we therefore determined whether these cells were present in the SGZ/GCL under basal conditions and after SE. Because microglia express both TNF receptors (Dopp 
et al., 1997), we also explored whether the deletion of TNF-R1 and/or TNF-R2 influenced the total number of microglia. To visualize microglia, we used Iba1, a marker that demonstrates both active and quiescent forms of microglia (Imai and Kohsaka, 2002). Iba1 ${ }^{+}$cells were scattered in the SGZ/GCL in all animal groups (Fig. $6 C)$. Under basal conditions, we detected no differences in the number of $\mathrm{Iba}^{+}{ }^{+}$cells between wild-type and TNF-R1 $1^{-/-}, T N F-$ $R 2^{-/-}$, and $T N F-R 1 / R 2^{-/-}$mice (Fig. $6 A)$. Similar to what we observed recently in rats (Bonde et al., 2006), we found that SE gives rise to chronic inflammation in the neurogenic SGZ/GCL area in mice. At 6 weeks after SE, we observed 50\% higher number of $\mathrm{Ibal}^{+}$cells in the SGZ/GCL in wild-type mice compared with the electrode-implanted, nonstimulated controls (Fig. 6C). The number of $\mathrm{Ibal}^{+}$cells was significantly reduced (by 23\%) in TNF-R $1^{-1-}$ mice. The lower cell number in these mice after SE was probably attributable to blockade of TNF- $\alpha$-induced microglia proliferation mediated by TNF-R1 (Dopp et al., 1997), possibly through an autocrine mechanism (Kuno et al., 2005). There was no significant correlation between the number of $\mathrm{Ibal}^{+}$cells and $\mathrm{BrdU}^{+} / \mathrm{NeuN}^{+}$cells in the SGZ/GCL of TNF-R $1^{-1-}$ mice after SE (Figs. $3 A, 6 B$ ). Surprisingly, the number of $\mathrm{Ibal}^{+}$cells in the SGZ/GCL was significantly higher in the TNF-R1/R2 $2^{-/-}$mice compared with wild-type animals. Most likely, this finding reflects the high percentage of generalized seizures during the $2 \mathrm{~h}$ of self-sustained SE in the TNF-R1/R2 $2^{-/-}$mice. Generalized seizures during SE are known to trigger stronger microglia activation than partial seizures (Ekdahl et al., 2003).

To assess other histological changes after SE that might have been influenced by the deletion of TNF-R1 and TNF-R2, we counted $\mathrm{S} 100 \beta^{+}$astrocytes and determined the occurrence of Fluoro-Jade ${ }^{+} \mathrm{de}$ generating neurons in the SGZ/GCL at 6 weeks after SE. Compared with the respective electrode-implanted, nonstimulated controls, the epileptic insult gave rise to $\sim 50 \%$ increase of $\mathrm{S} 100 \beta^{+}$cell counts in all groups. No significant differences in the number of $\mathrm{S} 100 \beta^{+}$in the SGZ/GCL cells were detected between wild-type (1732 \pm $41)$ and TNF-R1 $1^{-1-}(1634 \pm 15), T N F-$ $R 2^{-/-}(1726 \pm 38)$, and TNF-R1/R2 $2^{-1-}$

$(1705 \pm 27)$ mice after SE. Furthermore, we did not observe any Fluoro-Jade ${ }^{+}$cells in the SGZ/GCL in any group. In 3 of 42 $T N F-R 1 / R 2^{-/-}$mice, Fluoro-Jade ${ }^{+}$cells were observed in the hippocampal CA1 region (data not shown). From these results,
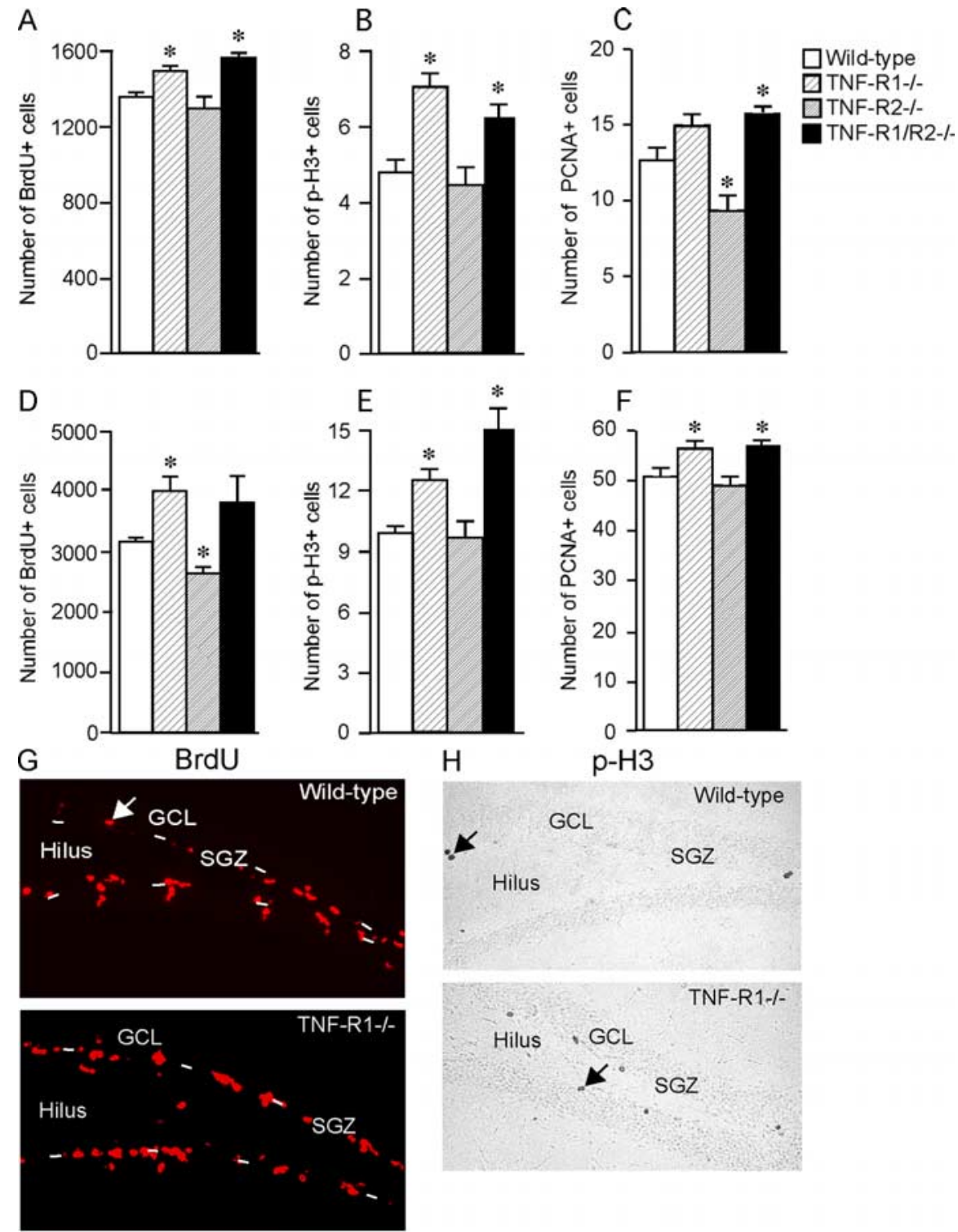

\section{$\mathrm{p}-\mathrm{H} 3$}
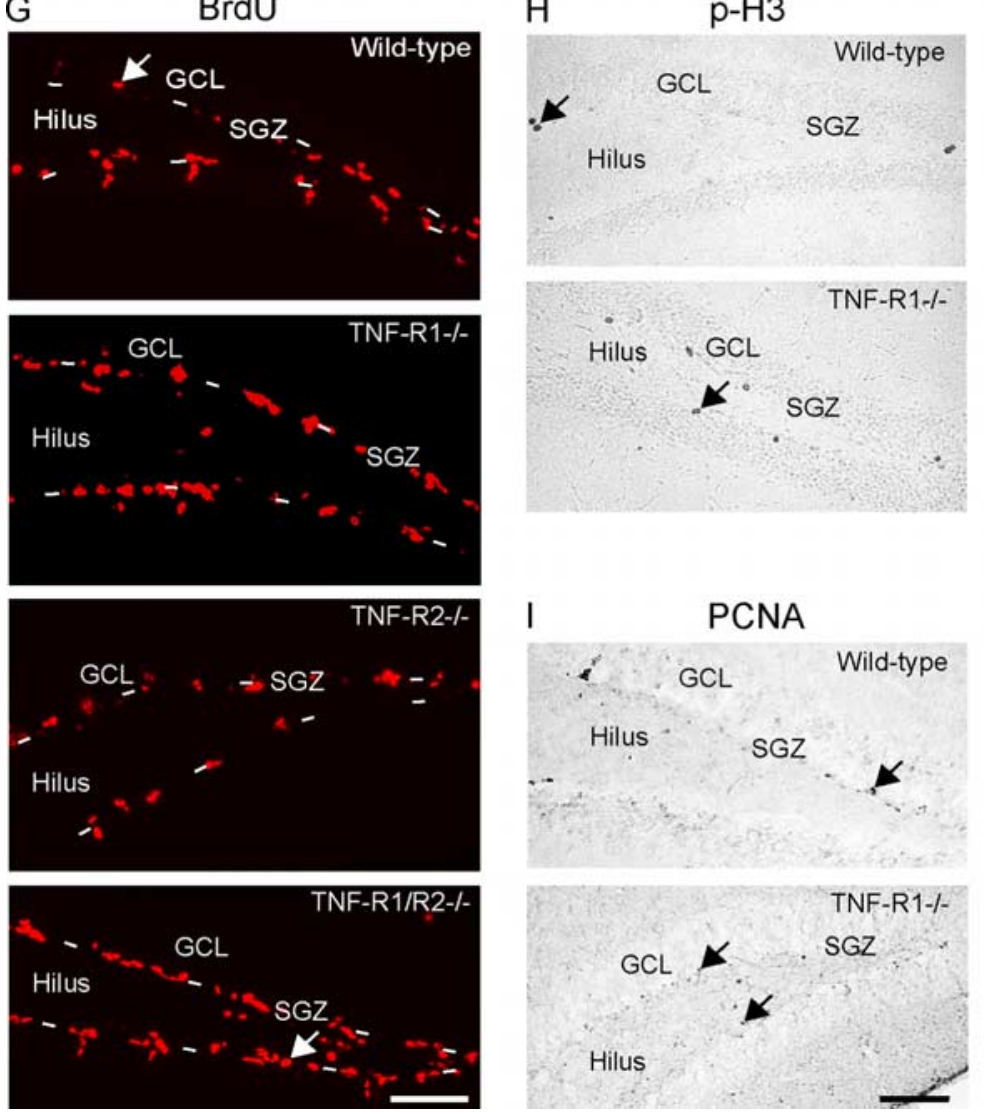

Figure 5. Deletion of TNF-R1 and TNF-R2 differentially affects hippocampal progenitor proliferation under basal conditions and after status epilepticus. $\boldsymbol{A}-\boldsymbol{F}$, Number of cells in the dentate $S G Z$ expressing the proliferation markers $\operatorname{BrdU}(\boldsymbol{A}, \boldsymbol{D}), \mathrm{p}-\mathrm{H} 3(\boldsymbol{B}, \boldsymbol{E})$, and PCNA $(\boldsymbol{C}, \boldsymbol{F})$ in intact mice $(\boldsymbol{A}-\boldsymbol{C})$ and at 1 week after electrically induced status epilepticus $(\boldsymbol{D}-\boldsymbol{F})$. BrdU had been injected four times with $2 \mathrm{~h}$ interval, and animals were perfused $2 \mathrm{~h}$ thereafter. Means \pm SEM; $n=5$ and 7,4 and 7,5 and 7 , and 5 and 7 for wild-type, $T N F-R 1^{-/-}, T N F-R 2^{-1-}$, and TNF-R1/R2 $2^{-1-}$ mice, respectively. ${ }^{*} p<0.05$ compared with wild-type, one-way ANOVA with Bonferroni-Dunn post hoc test. G-I, Photomicrographs showing distribution of BrdU ${ }^{+}(\boldsymbol{G}), \mathrm{p}-\mathrm{H} 3^{+}(\boldsymbol{H})$, and PCNA $^{+}$ cells $(I)$ in SGZ at 1 week after status epilepticus. Some BrdU ${ }^{+}$(red), p-H3 ${ }^{+}$(black), and PCNA ${ }^{+}$(black) cells in SGZ are depicted by arrows. Scale bar: $\mathbf{G}-\mathbf{I}, 70 \mu \mathrm{m}$. 
A

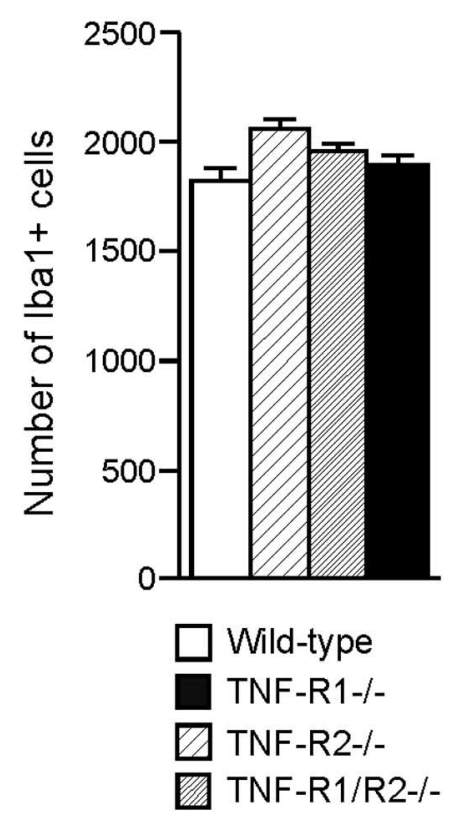

B

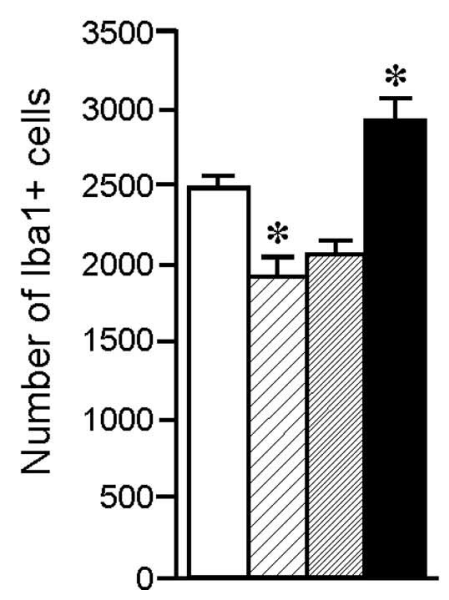

Figure 6. Deletion of TNF-R1 and TNF-R2 affects microglia in neurogenic area after status epilepticus. $\boldsymbol{A}, \boldsymbol{B}$, Numbers of Iba1 immunoreactive cells (showing both active and quiescent microglia) in the dentate SGZ/GCL under basal conditions $(\boldsymbol{A})$ and at 6

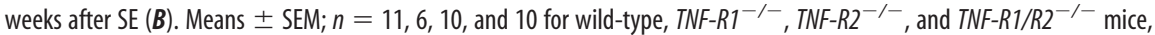
respectively. ${ }^{*} p<0.05$ compared with wild-type, one-way ANOVA with Bonferroni-Dunn post hoc test. C, Photomicrographs showing distribution of $\mathrm{Iba}^{+}{ }^{+}$cells in dentate hilus, SGZ, and GCL at 6 weeks after SE. Some Iba1 ${ }^{+}$cells (black) are depicted by arrows. Scale bar, $70 \mu \mathrm{m}$.

it seems inconceivable that the observed differential alterations of neurogenesis and progenitor proliferation after SE in mice lacking different TNF- $\alpha$ receptor subtypes were mediated indirectly through changes in astrocytosis or epileptic damage.

\section{Hippocampal progenitors express TNF- $\alpha$ and TNF-R1 and TNF-R2}

To investigate whether TNF- $\alpha$ and its receptors are expressed by the neural progenitors themselves, we sorted $\mathrm{GFP}^{+}$cells from hippocampi of nestin-GFP mice. In these mice, GFP is expressed under the nestin gene regulatory region. The $\mathrm{GFP}^{+}$cells have been shown to identify hippocampal neural stem and progenitor cells (Mignone et al., 2004). We isolated RNA from the sorted $\mathrm{GFP}^{+}$cells and, using reverse transcription (RT)-PCR, detected both TNF-R1 and TNF-R2, as well as TNF- $\alpha$ mRNA in the mouse hippocampal neural progenitor cells (Fig. 7A). TNF-R1, TNF-R2, and TNF- $\alpha$ mRNAs were also expressed in cultured rat hippocampal progenitors (Fig. 7A). Moreover, both TNF-R1 and TNF-R2 immunoreactivity was observed in the cultured hippocampal progenitors from adult rats (Fig. $7 B-G$ ). Together, our findings indicate that neural progenitor cells in the adult hippocampal formation can directly respond to signals mediated through TNF-R1 and TNF-R2.

\section{Discussion}

Using mouse models with loss of TNF-R1 or TNF-R2 function, we present here the first experimental evidence that signaling through TNF-R1 suppresses neural progenitor proliferation and neurogenesis in the adult brain in vivo. Using three different markers, cell proliferation in the dentate SGZ was found to be elevated in TNF$R 1^{-/-}$and $T N F-R 1 / R 2^{-/-}$mice both under basal conditions and when neurogenesis was stimulated by an epileptic insult. The TNF-R2 $2^{-/-}$mice showed either no change or a decrease of single proliferation markers. Supporting that the proliferating cells were neural progenitors, we observed in both intact and SE mice that the $\mathrm{BrdU}^{+}$cells were localized in typical clusters in the SGZ after short-term BrdU injections (Parent et al., 1997; Mohapel et al., 2004). Moreover, the higher numbers of mature neurons in TNF-R1 $1^{-/-}$and $T N F-R 1 / R 2^{-/-}$mice reflected the increased SGZ cell proliferation. Similarly, the lack of change of neurogenesis in the intact brain in TNF-R2 $2^{-/-}$mice agreed well with the minor alterations of cell proliferation in these animals. The reduction of the number of new mature neurons after SE suggests that TNF-R2 influences their survival in the pathological brain. Both receptors were found to be expressed on the progenitors themselves, indicating that the effects of the ligand can be mediated directly on these cells. Conditional TNF-R1 and TNF-R2 knock-out mice would have been preferable to determine the specific role of TNF receptor signaling in adult neurogenesis but are currently not available. However, we obtained no evidence from the morphological analyses or cytokine measurements of any developmental abnormalities in the animals used here that would explain the observed alterations of hippocampal progenitor proliferation and neurogenesis.

The action of TNF receptor signaling indicated by our data constitutes a novel mechanism for controlling neurogenesis in the adult brain. Our findings on the role of TNF-R1 are consistent with experimental evidence from other stem/progenitor cell systems. Activation of TNF-R1 suppressed proliferation of hematopoietic stem cells (Rusten et al., 1994; Bryder et al., 2001; Dybedal et al., 2001), and TNF- $\alpha$ inhibited proliferation of TNF-R1- 
expressing neural progenitors in neurospheres derived from neonatal rat striatum (Ben-Hur et al., 2003). Although the effect of TNF-R2 on hippocampal progenitor proliferation observed here was minor and only provided very weak evidence of a stimulatory role, TNF- $\alpha$ acting through TNF-R2 has in other studies been reported to promote proliferation of oligodendrocyte progenitors (Arnett et al., 2001) and erythroid cell lines (Chen et al., 2004) and to regulate thymocyte production by stimulating proliferation of early T lymphocyte precursors (Baseta and Stutman, 2000). However, in neither of these other systems was a physiological role of TNF- $\alpha$ and its receptors demonstrated. Here we show, using TNF-R1- and TNF-R2-deficient mice, that TNF- $\alpha$ is not only important in mediating suppressive effects on proliferation during inflammation associated with a brain insult but, most importantly, is involved in the regulation of turnover of neural stem/progenitor cells under physiological conditions.

The net effect of TNF- $\alpha$ on neurogenesis is most likely dependent on the levels of the cytokine and on the affinity and relative expression of TNF-R1 and TNF-R2 in the progenitor cells. TNF- $\alpha$ binds to TNF-R1 with high affinity, whereas TNF-R2 exhibits lower binding affinity in primary hippocampal neurons (Yang et al., 2002). Both receptor types are upregulated by injury, e.g., in retinal cells (Fontaine et al., 2002).

The intracellular mechanisms mediating the actions of TNF-R1 and TNF-R2 on progenitor proliferation and neurogenesis in vivo are not known. In cultures of primary mature neurons, the two receptors mediate opposing effects on cell survival through different signal transduction pathways (Yang et al., 2002; Marchetti et al., 2004). Both TNF-R1 and TNF-R2 induced the nuclear factor- $\kappa \mathrm{B}$ (NF$\kappa \mathrm{B})$ pathway in cortical neurons but with different kinetics and upstream activating components (Marchetti et al., 2004). TNF-R1 gave rise to transient NF- $\kappa \mathrm{B}$ activation, whereas TNF-R2 facilitated long-term phosphatidylinositol 3-kinasedependent NF- $\kappa \mathrm{B}$ activation. The persistent NF- $\kappa \mathrm{B}$ activity was necessary for the neuroprotective effect. Similar to what has been observed in the majority of other cell systems (Wajant et al., 2003), TNF-R1 appears to be the key mediator of TNF signaling also in the hippocampal progenitors. Mice in which both receptors had been deleted exhibited SGZ cell proliferation closely resembling that in mice lacking only TNF-R1. The marked reduction in the number of mature new neurons in the TNF- $R 2^{-1-}$ mice subjected to SE was most likely not a consequence of the minor and inconsistent decrease of cell proliferation. This finding probably indicates that TNF-R2 can mediate a neuroprotective action on the new neurons formed from hippocampal progenitors similar to that reported for retinal cells (Fontaine et al., 2002) and cortical neurons (Marchetti et al., 2004). Such an action is also suggested by our observation that infusion of an antibody to TNF- $\alpha$ reduced the number of new striatal and hip- pocampal neuroblasts after stroke (Heldmann et al., 2005). The effect on survival in the present study was only observed after SE, which raises the possibility that the epileptic insult had triggered upregulation of TNF-R2 (cf. Balosso et al., 2005).

We observed that the hippocampal progenitors in mice expressed the TNF- $\alpha$ gene, similar to what has been reported previously in rats and humans (Klassen et al., 2003). Thus, the ligand acting on the TNF-R1 and TNF-R2 receptors could originate from the hippocampal progenitors themselves. However, the most important role is probably played by microglia-derived TNF- $\alpha$. Microglia cells were distributed in the SGZ/GCL in all animal groups both under basal conditions and after SE. Interestingly, Battista et al. (2006) recently provided evidence that microglia are part of this neurogenic niche. The activation of microglia was not pro-neurogenic or anti-neurogenic per se but dependent on the balance between the secreted molecules with pro-inflammatory and anti-inflammatory actions (Battista et al., 2006). Our data do not support the idea that the observed consequences of TNF-R1 and TNF-R2 deletion on neurogenesis were indirect and dependent on the number of microglia cells. Iba1 ${ }^{+}$ microglia were fewer in TNF- $R 1^{-/-}$mice compared with wildtype animals after SE, which, if assuming an anti-neurogenic effect of microglia, could contribute to the higher number of new neurons in the SGZ/GCL. Arguing against this possibility, we found no correlation between numbers of $\mathrm{BrdU}^{+} / \mathrm{NeuN}^{+}$cells 
and $\mathrm{Iba}^{+}$cells in TNF-R1-1- mice subjected to SE. Also, no difference in the occurrence of microglia was observed under basal conditions when increased neurogenesis and proliferation were also found in the TNF-R1 $1^{-1-}$ mice. Finally, the number of Iba1 ${ }^{+}$cells was unchanged in TNF-R2 $2^{-1-}$ mice after SE, but $\mathrm{BrdU}^{+} / \mathrm{NeuN}^{+}$cells were fewer than in wild-type animals.

It is unlikely that the changes in neurogenesis after SE were reflecting alterations of seizure susceptibility. Status epilepticus induces elevated hippocampal levels of TNF- $\alpha$ (De Simoni et al., 2000), and a recent experimental study indicates that TNF- $\alpha$ inhibits seizures through TNF-R2 (Balosso et al., 2005). We observed no difference between TNF- $R 1^{-1-}$ and TNF- $R 2^{-1-}$ mice and wild-type animals in seizure characteristics during SE. Furthermore, if more prolonged seizure activity had occurred in the TNF-R2 $2^{-1-}$ mice (Balosso et al., 2005), it would most likely have lead to enhanced neurogenesis. In contrast, we found reduced numbers of new cells in these animals.

Here we have demonstrated the involvement of TNF-R1 and TNF-R2 signaling in the regulation of adult hippocampal neurogenesis. Our data indicate that TNF- $\alpha$ can modulate the formation of new neurons under both physiological and pathological conditions by acting on these two receptors with differential effects on proliferation and survival. Circumstantial evidence indicates a link between hippocampal neurogenesis and cognitive function (Abrous et al., 2005). TNF- $\alpha$ is a key player in many pathological processes and is increased in the CSF of patients, e.g., with mild cognitive impairment (Tarkowski et al., 2003b), Alzheimer's disease and vascular dementia (Tarkowski et al., 2003a), and stroke (Sairanen et al., 2001; Zaremba and Losy, 2001). Our data suggests selective suppression of TNF-R1 and enhancement of TNF-R2 signaling as a possible novel strategy to optimize hippocampal neurogenesis and stimulate cognitive function in the intact and diseased brain.

\section{References}

Abrous DN, Koehl M, Le Moal M (2005) Adult neurogenesis: from precursors to network and physiology. Physiol Rev 85:523-569.

Arnett HA, Mason J, Marino M, Suzuki K, Matsushima GK, Ting JP (2001) TNF alpha promotes proliferation of oligodendrocyte progenitors and remyelination. Nat Neurosci 4:1116-1122.

Balosso S, Ravizza T, Perego C, Peschon J, Campbell IL, De Simoni MG, Vezzani A (2005) Tumor necrosis factor-alpha inhibits seizures in mice via p75 receptors. Ann Neurol 57:804-812.

Baseta JG, Stutman O (2000) TNF regulates thymocyte production by apoptosis and proliferation of the triple negative (CD3-CD4-CD8-) subset. J Immunol 165:5621-5630.

Battista D, Ferrari CC, Gage FH, Pitossi FJ (2006) Neurogenic niche modulation by activated microglia: transforming growth factor beta increases neurogenesis in the adult dentate gyrus. Eur J Neurosci 23:83-93.

Ben-Hur T, Ben-Menachem O, Furer V, Einstein O, Mizrachi-Kol R, Grigoriadis N (2003) Effects of proinflammatory cytokines on the growth, fate, and motility of multipotential neural precursor cells. Mol Cell Neurosci 24:623-631.

Bonde S, Ekdahl CT, Lindvall O (2006) Long-term neuronal replacement in adult rat hippocampus after status epilepticus despite chronic inflammation. Eur J Neurosci 23:965-974.

Bryder D, Ramsfjell V, Dybedal I, Theilgaard-Monch K, Hogerkorp CM, Adolfsson J, Borge OJ, Jacobsen SE (2001) Self-renewal of multipotent long-term repopulating hematopoietic stem cells is negatively regulated by Fas and tumor necrosis factor receptor activation. J Exp Med 194:941-952.

Cacci E, Claasen JH, Kokaia Z (2005) Microglia-derived tumor necrosis factor-alpha exaggerates death of newborn hippocampal progenitor cells in vitro. J Neurosci Res 80:789-797.

Chen J, Jacobs-Helber SM, Barber DL, Sawyer ST (2004) Erythropoietindependent autocrine secretion of tumor necrosis factor-alpha in hematopoietic cells modulates proliferation via MAP kinase-ERK-1/2 and does not require tyrosine docking sites in the EPO receptor. Exp Cell Res 298:155-166.

De Simoni MG, Perego C, Ravizza T, Moneta D, Conti M, Marchesi F, De Luigi A, Garattini S, Vezzani A (2000) Inflammatory cytokines and related genes are induced in the rat hippocampus by limbic status epilepticus. Eur J Neurosci 12:2623-2633.

Depuydt B, van Loo G, Vandenabeele P, Declercq W (2005) Induction of apoptosis by TNF receptor 2 in a T-cell hybridoma is FADD dependent and blocked by caspase- 8 inhibitors. J Cell Sci 118:497-504.

Dolbeare F (1995) Bromodeoxyuridine: a diagnostic tool in biology and medicine. I. Historical perspectives, histochemical methods and cell kinetics. Histochem J 27:339-369.

Dopp JM, Mackenzie-Graham A, Otero GC, Merrill JE (1997) Differential expression, cytokine modulation, and specific functions of type- 1 and type-2 tumor necrosis factor receptors in rat glia. J Neuroimmunol $75: 104-112$.

Dybedal I, Bryder D, Fossum A, Rusten LS, Jacobsen SE (2001) Tumor necrosis factor (TNF)-mediated activation of the p55 TNF receptor negatively regulates maintenance of cycling reconstituting human hematopoietic stem cells. Blood 98:1782-1791.

Ekdahl CT, Claasen JH, Bonde S, Kokaia Z, Lindvall O (2003) Inflammation is detrimental for neurogenesis in adult brain. Proc Natl Acad Sci USA 100:13632-13637.

Fontaine V, Mohand-Said S, Hanoteau N, Fuchs C, Pfizenmaier K, Eisel U (2002) Neurodegenerative and neuroprotective effects of tumor necrosis factor (TNF) in retinal ischemia: opposite roles of TNF receptor 1 and TNF receptor 2. J Neurosci 22:RC216(1-7).

Gage FH, Coates PW, Palmer TD, Kuhn HG, Fisher LJ, Suhonen JO, Peterson DA, Suhr ST, Ray J (1995) Survival and differentiation of adult neuronal progenitor cells transplanted to the adult brain. Proc Natl Acad Sci USA 92:11879-11883.

Gebicke-Haerter PJ (2001) Microglia in neurodegeneration: molecular aspects. Microsc Res Tech 54:47-58.

Gundersen HJ, Jensen EB (1987) The efficiency of systematic sampling in stereology and its prediction. J Microsc 147:229-263.

Hallenbeck JM (2002) The many faces of tumor necrosis factor in stroke. Nat Med 8:1363-1368.

Heldmann U, Thored P, Claasen JH, Arvidsson A, Kokaia Z, Lindvall O (2005) TNF-alpha antibody infusion impairs survival of strokegenerated neuroblasts in adult rat brain. Exp Neurol 196:204-208.

Hirsch EC, Breidert T, Rousselet E, Hunot S, Hartmann A, Michel PP (2003) The role of glial reaction and inflammation in Parkinson's disease. Ann NY Acad Sci 991:214-228.

Imai Y, Kohsaka S (2002) Intracellular signaling in M-CSF-induced microglia activation: role of Iba1. Glia 40:164-174.

Klassen HJ, Imfeld KL, Kirov II, Tai L, Gage FH, Young MJ, Berman MA (2003) Expression of cytokines by multipotent neural progenitor cells. Cytokine 22:101-106.

Komitova M, Mattsson B, Johansson BB, Eriksson PS (2005) Enriched environment increases neural stem/progenitor cell proliferation and neurogenesis in the subventricular zone of stroke-lesioned adults rats. Stroke $36: 1278-1282$.

Kralic JE, Ledergerber DA, Fritschy JM (2005) Disruption of the neurogenic potential of the dentate gyrus in a mouse model of temporal lobe epilepsy with focal seizures. Eur J Neurosci 22:1916-1927.

Kuno R, Wang J, Kawanokuchi J, Takeuchi H, Mizuno T, Suzumura A (2005) Autocrine activation of microglia by tumor necrosis factor-alpha. J Neuroimmunol 162:89-96.

Lothman EW, Bertram EH, Bekenstein JW, Perlin JB (1989) Self-sustaining limbic status epilepticus induced by "continuous" hippocampal stimulation: electrographic and behavioral characteristics. Epilepsy Res 3:107-119.

Marchetti L, Klein M, Schlett K, Pfizenmaier K, Eisel UL (2004) Tumor necrosis factor (TNF)-mediated neuroprotection against glutamateinduced excitotoxicity is enhanced by $N$-methyl-D-aspartate receptor activation. Essential role of a TNF receptor 2-mediated phosphatidylinositol 3-kinase-dependent NF-kappa B pathway. J Biol Chem 279:32869-32881.

Mignone JL, Kukekov V, Chiang AS, Steindler D, Enikolopov G (2004) Neural stem and progenitor cells in nestin-GFP transgenic mice. J Comp Neurol 469:311-324.

Mohapel P, Ekdahl CT, Lindvall O (2004) Status epilepticus severity influ- 
ences the long-term outcome of neurogenesis in the adult dentate gyrus. Neurobiol Dis 15:196-205.

Monje ML, Toda H, Palmer TD (2003) Inflammatory blockade restores adult hippocampal neurogenesis. Science 302:1760-1765.

Navikas V, Link H (1996) Review: cytokines and the pathogenesis of multiple sclerosis. J Neurosci Res 45:322-333.

Palmer TD, Takahashi J, Gage FH (1997) The adult rat hippocampus contains primordial neural stem cells. Mol Cell Neurosci 8:389-404.

Parent JM, Yu TW, Leibowitz RT, Geschwind DH, Sloviter RS, Lowenstein DH (1997) Dentate granule cell neurogenesis is increased by seizures and contributes to aberrant network reorganization in the adult rat hippocampus. J Neurosci 17:3727-3738.

Paunesku T, Mittal S, Protic M, Oryhon J, Korolev SV, Joachimiak A, Woloschak GE (2001) Proliferating cell nuclear antigen (PCNA): ringmaster of the genome. Int J Radiat Biol 77:1007-1021.

Peschon JJ, Torrance DS, Stocking KL, Glaccum MB, Otten C, Willis CR, Charrier K, Morrissey PJ, Ware CB, Mohler KM (1998) TNF receptordeficient mice reveal divergent roles for p55 and p75 in several models of inflammation. J Immunol 160:943-952.

Pickering M, Cumiskey D, O'Connor JJ (2005) Actions of TNF-alpha on glutamatergic synaptic transmission in the central nervous system. Exp Physiol 90:663-670.

Racine RJ (1972) Modification of seizure activity by electrical stimulation. I. After-discharge threshold. Electroenecphalogr Clin Neurophysiol 32:269-279.

Raina N, Jeejeebhoy KN (2004) Effect of low-protein diet and protein supplementation on the expressions of TNF-alpha, TNFR-I, and TNFR-II in organs and muscle of LPS-injected rats. Am J Physiol Endocrinol Metab 286:E481-E487.

Reddy J, Chastagner P, Fiette L, Liu X, Theze J (2001) IL-2-induced tumor necrosis factor (TNF)-beta expression: further analysis in the IL-2 knockout model, and comparison with TNF-alpha, lymphotoxin-beta, TNFR1 and TNFR2 modulation. Int Immunol 13:135-147.
Rusten LS, Smeland EB, Jacobsen FW, Lien E, Lesslauer W, Loetscher H, Dubois CM, Jacobsen SE (1994) Tumor necrosis factor-alpha inhibits stem cell factor-induced proliferation of human bone marrow progenitor cells in vitro. Role of p55 and p75 tumor necrosis factor receptors. J Clin Invest 94:165-172.

Sairanen T, Carpen O, Karjalainen-Lindsberg ML, Paetau A, Turpeinen U, Kaste M, Lindsberg PJ (2001) Evolution of cerebral tumor necrosis factor-alpha production during human ischemic stroke. Stroke $32: 1750-1758$.

Schmued LC, Albertson C, Slikker Jr W (1997) Fluoro-Jade: a novel fluorochrome for the sensitive and reliable histochemical localization of neuronal degeneration. Brain Res 751:37-46.

Sheng WS, Hu S, Ni HT, Rowen TN, Lokensgard JR, Peterson PK (2005) TNF-alpha-induced chemokine production and apoptosis in human neural precursor cells. J Leukoc Biol 78:1233-1241.

Tarkowski E, Andreasen N, Tarkowski A, Blennow K (2003a) Intrathecal inflammation precedes development of Alzheimer's disease. J Neurol Neurosurg Psychiatry 74:1200-1205.

Tarkowski E, Liljeroth AM, Minthon L, Tarkowski A, Wallin A, Blennow K (2003b) Cerebral pattern of pro- and anti-inflammatory cytokines in dementias. Brain Res Bull 61:255-260.

Wajant H, Pfizenmaier K, Scheurich P (2003) Tumor necrosis factor signaling. Cell Death Differ 10:45-65.

West MJ, Slomianka L, Gundersen HJ (1991) Unbiased stereological estimation of the total number of neurons in the subdivisions of the rat hippocampus using the optical fractionator. Anat Rec 231:482-497.

Yang L, Lindholm K, Konishi Y, Li R, Shen Y (2002) Target depletion of distinct tumor necrosis factor receptor subtypes reveals hippocampal neuron death and survival through different signal transduction pathways. J Neurosci 22:3025-3032.

Zaremba J, Losy J (2001) Early TNF-alpha levels correlate with ischaemic stroke severity. Acta Neurol Scand 104:288-295. 